\title{
PENGGUNAAN MEDIA PEMBELAJARAN GAME ONLINE BASED LEARNING PADA MATERI TEKS DESKRIPSI
}

\author{
Nadia Rahmah \\ E-mail: nadia.rahmah0577@student.unri.ac.id \\ Program Studi Pendidikan Bahasa dan Sastra Indonesia, Universitas Riau
}

\section{Pengantar}

Media pembelajaran merupakan alat yang digunakan dalam proses belajar mengajar. Media pembelajaran menurut Arsyad (2002:3) menyatakan media pembelajaran adalah segala hal yang dapat dipergunakan untuk merangsang pikiran, perhatian, kemampuan dan keterampilan belajar serta mendorong terjadinya proses belajar-mengajar yang lebih efektif.

Media pembelajaran dapat dibagi menjadi beberapa bagian yaitu media cetak, media grafis, dan media audio (Mehra, 1992) selain itu media pembelajaran juga bisa dikelompokkan kedalam media perangkat keras dan perangkat lunak / ELearning (Omodara, 2014).

Media pembelajaran memiliki peran yang berpengaruh dalam keberhasilan kegiatan belajar-mengajar. Menurut Killen tahun 2003 menyatakan bahwa media sangat berguna sebagai sarana untuk kegiatan belar-mengajar yang interaktif dan komunikatif, serta lebih mempermudah guru dalam menyampaikan materi pembelajaran dalam bentuk inovasi media pembelajaran yang kreatif dan inovatif.

Salah satu bentuk inovasi media pembelajaran yang kreatif dan inovatif dalam ruang lingkup mata pelajaran Bahasa Indonesia adalah menggunakan media pembelajaran game online based learning pada materi teks deskripsi. Penggunaan media pembelajaran ini dapat menarik perhatian para siswa dan membantu mereka dalam menemukan jawaban dan informasi terkait materi teks deskripsi secara mandiri.

Menurut penulis salah satu alasan menciptakan media pembelajaran inovatif ini dilatarbelakangi oleh semakin kurangnya ketertarikan para peserta didik untuk mengikuti mata pelajaran Bahasa Indonesia, terutama minimnya respon peserta 
didik untuk menyimak materi teks deskripsi secara daring. Hal ini dibuktikan dari kurangnya minat peserta didik yang aktif bertanya, menjawab maupun berpartisipasi ketika mengikuti kegiatan pembelajaran secara daring terutama dalam mata pelajaran Bahasa Indonesia pada materi mengidentifikasi konsep teks deskripsi secara umum, mengenal struktur teks deskripsi, pola penyajiannya, tujuan pembuatan teks deskripsi dan mengenal serta mampu menciptakan teks deskripsi yang lebih kreatif.

\section{Tindakan yang Dilakukan}

\section{a. Mempersiapkan pendidik dan peserta didik.}

Mempersiapkan pendidik berarti bahwa para guru siap secara jasmani dan rohani untuk memulai kegiatan pembelajaran. Persiapan pendidik biasanya dilihat dari kesiapan bahan ajar yang mendukung kegiatan pembelajaran yakni bahan ajar teks deskripsi. Adapun bahan ajar teks deskripsi meliputi konsep umum teks deskripsi yaitu karangan yang menggambarkan suatu objek berdasarkan hasil pengamatan, perasaan, dan pengalaman penulisnya (Daeng, 2016;93).

Menurut Mahsun $(2014 ; 45)$ Kesiapan bahan ajar terkait teks deskripsi yang akan disampaikan oleh pendidik juga meliputi penyajian struktur teks deskrisi yang antara lain: judul, deskripsi umum tentang objek yang di deskripsikan dan deskripsi bagian yang menjelaskan pengklasifikasian objek yang di deskripsikan.

Selain itu kesiapan bahan ajar tentang materi teks deskripsi yang harus dipersiapkan oleh pendidik adalah uraian pola penyajian teks deskripsi yakni pola urutan penyajian yang mencakup persoalan-persoalan tentang suatu hal yang dapat dipandang (Keraf, 1981;138-141).

Mempersiapkan peserta didik berarti bahwa peserta didik sanggup untuk mengikuti kegiatan pembelajaran mata pelajaran Bahasa Indonesia yang saat itu mambahas materi teks deskripsi. Peserta didik memiliki kesiapan baik itu kesiapan dalam kesehatan, kepokusan menerima pembelajaran tentang teks 
deskripsi maupun kesiapan menyediakan perangkat pembelajaran atau sarana pendukung kegiatan pembelajaran demi memahami materi teks deskripsi.

\section{b. Curah pengalaman terkait dengan materi teks deskripsi.}

Curah pengalaman terkait teks deskripsi berarti antara peserta didik dan pendidik saling berbagi informasi terkait pengetahuan tentang teks deskripsi. Hal ini bisa dilakukan lewat komunikasi interaktif antara pendidik dan peserta didik seperti diskusi dengan menggunakan zoom, googlemeet, classroom, dsb.

\section{c. Mencari dan menemukan platform pembelajaran berbasis game online yang dapat memfasilitasi materi teks deskripsi.}

Maksud dari poin c adalah pendidik dapat mencari dan menemukan aplikasi pembelajaran yang dapat memfasilitasi penyampaian dan pendalaman materi teks deskripsi kepada peserta didik melalui aplikasi game online based learning seperti aplikasi Quiziz dan Kahoot.

Proses pencarian kedua aplikasi tersebut bisa dilakukan oleh pendidik melalui searching di google maupun membaca berbagai artikel jurnal maupun skripsi penelitian yang membahas tentang penggunaan media digital game based learning untuk meningkatkan pemahaman terhadap teks deskripsi.

\section{d. Daftar atau login di platform game online based learning}

Daftar atau login di platform game online based learning maksudnya adalah pendidik terlebih dahulu mendaftar di aplikasi game online based learning yang akan digunakan. Misalnya pendidik menggunakan aplikasi Quizizz untuk menyajikan rentetan pertanyaan kepada peserta didik terkait konsep umum teks deskripsi, struktur teks deskripsi, pola penyajiannya, tujuan pembuatan teks deskripsi serta menciptakan teks deskripsi yang lebih kreatif. Maka cara membuat akun Quizizz antara lain:

1. Masuk ke situs https://quizizz.com/

2. Klik sign up 
Bisa sign up dengan menggunakan akun google, atau dengan memasukkan email.

3. Setelah berhasil, silahkan klik $\underline{\text { a teacher }}$

4. selanjutnya

- Pilih negara

- Masukkan kode pos

- Masukkan nama sekolah secara manual dengan cara klik can’t find your organization

- Klik add organization

- Klik continue.

\section{e. Membuat rentetan kuis terkait materi teks deskripsi di aplikasi tersebut.}

Setelah berhasil membuat akun Quizizz, Langkah selanjutnya adalah membuat rincian pertanyaan di akun tersebut. Adapun cara membuat soal di Quizizz adalah sebagai berikut:

1. Klik open quiz creator

2. Selanjutnya

- Masukkan nama kuis dengan 'kuis teks deskripsi'”.

- Pilih Bahasa yang akan digunakan.

- Masukkan gambar yang dapat mengilustrasikan teks deskripsi.

3. Klik create new questions untuk memulai membuat soal.

4. Lalu klik single answer atau multy select.

5. Maka rincian soal seputar teks deskripsi siap diproses dan disajikan.

Dan setelah soal siap disajikan, silahkan membagikan link soal tersebut kepeserta didik, namun peserta didik harus memiliki akun quiziz terlebih dahulu.

f. Membagikan link game online based learning terkait pertanyaanpertanyaan yang terkait materi teks deskripsi. 
Membagikan link game online based learning (Quizizz) yang berisi pertanyaan seputar teks deskripsi tadi bisa dibagikan lewat media chat diwhatsapp, membagikannya diroom classroom dan chatting di intagram.

\section{Sarana Pendukung}

a. Android/ notebook/ laptop, dsb.

b. Kuota internet/ wifi, hospot.

c. Jaringan internet.

d. WhatsApp/ telegram/ google classroom/google meet/ nomor telepon biasa.

e. Platform game online based learning seperti Quiziz dan Kahoot.

f. Website terkait pembelajaran daring.

g. Buku pelajaran materi teks deskripsi untuk mencari rincian pertanyaan dan sebagai pegangan bagi siswa dalam mencari jawaban terkait materi teks deskripsi.

h. E-book/ artikel/jurnal terkait materi teks deskripsi.

Selanjutnya Sumintono tahun 2012 menegaskan bahwa kegiatan belajar mengajar sangat membutuhkan teknologi. Teknologi ini dapat berperan sebagai sarana pendukung media pembelajaran. Terutama penggunaan sarana android/kamputer/ notebook/ laptop dalam penerapan media pembelajaran game online based learning pada materi teks deskripsi. Selain itu, Hennessy dkk dalam Ghavidekr \& Rosdy juga menyatakan bahwa perkembangan teknologi dan terbentuknya berbagai inovasi dalam media pembelajaran membuat proses belajarmengajar semakin bermamfat jika para tenaga pendidik semakin memiliki kemampuan kepercayaan diri untuk mengeksploitasi kompetensi dirinya dalam menggunakan teknologi sebagai media pembelajaran.

Berikut ini adalah disajikan efektivitas penggunaan media pembelajaran game online based learning atau bisa dikenal dengan Digital Game Based Learning (DGBL) yang berhubungan dengan kompetensi peserta didik sebagai berikut ini; 


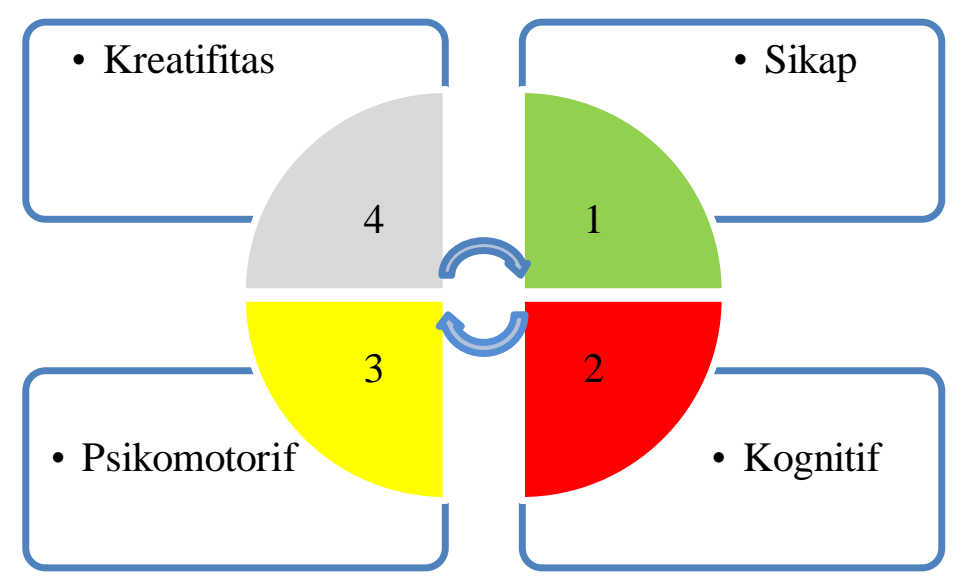

Gambar 1. Kompetensi Peserta Didik

Penggunaan media pembelajaran game online based learning diharapkan dapat meningkatkan kompetensi Sikap peserta didik yang meliputi aspek menerima, merespon, menilai, mengorganisasi, dan berkarakter pada diri peserta didik dalam menyerap materi pembelajaran terkait teks deskripsi.

Selain itu, penggunaan media pembelajaran ini juga diharapkan dapat meningkatkan kompetensi Kognitif peserta didik pada materi teks deskripsi yang ditandai dengan kemampuan untuk memenuhi 6 (enam) jenjang proses yaitu kemampuan menghapal, memahami, menerapkan, menganalisis, mensintesis, dan mengevaluasi teks deskripsi.

Selanjutnya kompetensi Psikomotorif peserta didik yang diharapkan dari penggunaan media pembelajaran game online based learning adalah keterampilan peserta didik dalam memenuhi aspek imitasi, manipulasi, presisi, dan naturalisasi teks deskripsi.

Sedangkan kompetensi Kreatifitas peserta didik dengan penggunaan media pembelajaran ini adalah keterampilan mereka untuk menciptakan atau menggunakan strategi inovatif dan kreatif dalam rangka menyerap, menangkap dalam menemukan pengetahuan terkait tentang materi teks deskripsi.

\section{Tindakan Solutif}


a. Jika terkendala dari segi memiliki android/ notebook/ laptop maka pinjamlah android/ notebook/ laptop milik saudara/ teman/ orang lain/ pergi ke warnet/ bergabung dengan teman yang memadai sarana pendukung satu ini.

b. Jika terkendala dari segi kuota internet/ wifi/ hospot, maka lakukan segala upaya dalam menyelesaikan halangan tersebut, misalnya minta wifi/ hospot orang lain yang menyediakan fasilitas wifi gratis.

c. Jika terkendala dari jaringan internet yang tidak stabil di daerah tempat tinggal, maka pindahlah ketempat yang menyediakan jaringan internet yang stabil atau pergi ke daerah perkotaan yang memiliki jaringan internet bagus.

d. Jika terkendala pada sarana pendukung bagian whatapp maka pakailah telegram begitupun sebaliknya, jika terkendala pada penggunaan classroom maka pakailah google meet atau zoom begitu sebaliknya, dan jika masih terdapat kendala pada bagian ini maka langsung saja berkomunikasi lewat telepon biasa melalui saluran telepon biasa, sms atau calllet dan begitu sebaliknya.

e. Jika terdapat kendala dalam pembuatan akun dan pengoperasian aplikasi Quizizz atau Kahoot maka tontonlah tutorial pembuatan akun dan pengoperasian aplikasi tersebut di youtube agar mempermudah dalam membuat rentetan pertanyaan-pertanyaan terkait materi teks deskripsi dengan memanfatkan aplikasi Quizizz atau Kahoot.

f. Jika mendapat kendala dalam membuat pertanyaan-pertanyaan terkait materi teks deskripsi melalui apk Quizizz atau Kahoot, maka gunaan aplikas Youtobe atau searcing di Google untuk mencari tutorial membuat pertanyaan melalui apk Quizizz atau Kahoot.

g. Jika mendapat halangan dalam membagikan link apk game online (Quizizz atau Kahoot) yang sudah berisikan pertanyan-pertanyaan terkait teks deskripsi, maka tontonlah kembali tutorial membagikan link tersebut di Youtube atau bertanya langsung kepada peneliti terdahulu/ sarjana komunikasi yang membahas tentang penggunaan media pembelajaran game online based learning (Quizizz atau Kahoot) dalam hal membagikan link aplikasi Quizizz atau Kahoot yang sudah memuat pertanyaan-pertanyaan tentang definisi teks 
deskripsi, struktur dan pola penyajian teks deskripsi, pola Bahasa teks deskripsi, bentuk-bentuk teks deskripsi, langkah-langkah membuat teks deskripsi dan contoh teks deskripsi.

\section{Simpulan}

Media pembelajaran merupakan sarana untuk kegiatan belajar-mengajar yang interaktif, komunikatif, inovatif, dan kreatif yang dapat memperluas pengetahuan pendidik dan peserta didik. Media pembelajaran memegang peranan penting untuk menyampaikan berbagai informasi atau ilustrasi yang dapat mendukung (M.Nur Mustafa \& Zulhafizh ; 2018)

Perkembangan teknologi dan terbentuknya berbagai inovasi dalam media pembelajaran membuat proses belajar-mengajar semakin bermamfat jika para tenaga pendidik semakin memiliki kemampuan kepercayaan diri untuk mengeksploitasi kompetensi dirinya dalam menggunakan teknologi sebagai media pembelajaran.

Penggunaan media pembelajaran game online based learning juga dapat meningkatkan kemampuan sikap, kognitif, psikomotorif, kreatifitas peserta didik dalam menyerap materi pembelajaran khususnya materi deskripsi.

\section{Referensi}

Link google scholar https://scholar.google.co.id/citations?view_op=view_citation\&hl=id\&user= tgwzJWAAAAAJ\&citation_for_view=tgwzJWAAAAAJ:hMod-77fHWUC

https://scholar.google.co.id/citations?view_op=view_citation\&hl=id\&user= tgwzJWAAAAAJ\&citation_for_view=tgwzJWAAAAAJ:UebtZRa9Y70C

Daftar rujukan

http://lib.unnes.ac.id/28068/

khoerunnisa, Ferninda. (2016). Penggunaan Media Digital Game-Based-Learning (DGBL) Untuk Meningkatkan Hasil Belajar Siswa Pada Pembelajaran Perakitan Komputer di SMKN 8 Semarang. Skripsi (Pendidikan Teknik Informatika dan Komputer),33-79 
http://eprints.unm.ac.id/10387/1/ARTIKEL/

Ulfa, Nurul, dkk. (2016). Keterampilan Menulis Teks Deskripsi Bahasa Makassar Melalui Media Gambar Siswa Kelas VII SMPN 1 Bajeng Barat Kabupaten Gowa. Bahasa dan Sastra, 1-7.

Motivasi dan hasil belajar https://www.researchgate.net/profile/Zulhafizh_Zulhafizh/publication/328 665695_The_Significance_of_Language_Motivation_Learning_Correlatio n_Analysis/links/5ea7d74a92851c1a90766587/The-Significance-ofLanguage-Motivation-Learning-Correlation-Analysis.pdf

Mustafa, M. N., Hermandra, Zulhafizh, \& Hermita, N. (2018). The Significance of Language Motivations Learning: Correlation Analysis. Advanced Science Letters, 24(11), 8080-8083.

Media pembelajaran

https://jes.ejournal.unri.ac.id/index.php/JES/article/download/6972/6177

Mustafa, M. N., Hermandra, \& Zulhafizh. (2019). Teachers' Strategies to Design Media to Implement Communicative Leaning in Public Schools. Journal of Educational Sciences, 3(1), 13-24.

Mehra, V. (1992). Instructional system design an innovation in educational Technology. Delhi: S. S. Publishers.

Omodara, O. D., \& Adu, E. I. (2014). Relevance of educational media and Multimedia technology for effective service delivery in teaching and Learning processes. IOSR Journal of Research \& Method in Education (IOSR-JRME), 4(2), 48-5.

Prasetyo, L Adhi. 2015. Pengembangan Game Edukasi Perakitan Komputer untuk Peserta Didik SMK Batik Perbaik Purworejo. Jurnal Elektronik Pendidikan Teknik Informatika (EJPTI). 4(5). 


\section{*Data Penulis}

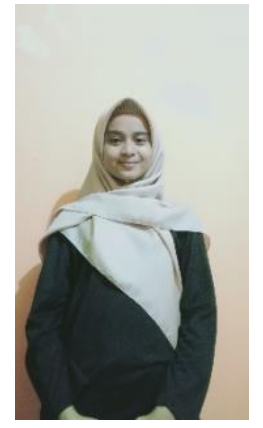

Nadia Rahmah, lahir di Ganting Damai, 24 Agustus 2001. Pada tahun akademik 2020, SMAN 1 Bangkinang Tahun 2018-2020, dan melanjutkan studi pada Program Studi Pendidikan Bahasa dan Sastra Indonesia FKIP Universitas Riau melalui jalur SNMPTN (Seleksi Nasional Masuk Perguruan Tinggi), peran media sosial pada masa pandemic (essay).

Kontak

$\mathrm{Hp} / \mathrm{WA} \quad$ : 082311583638

Email : nadia.rahma0577@student.unri.ac.id 